\title{
ESSAY
}

\section{InCRemental, Systemic, and Paradigmatic Reform of InVESTOR-STATE ARbitration}

\author{
By Anthea Roberts*
}

In Imperfect Alternatives: Institutional Choice and the Reform of Investment Law, Sergio Puig and Gregory Shaffer introduce comparative institutional analysis to evaluate alternative processes for resolving investment disputes. ${ }^{1}$ The impetus for this article is clear: many states view investor-state arbitration as akin to a horse that has bolted from the barn. Wishing to close the stable door, a wide range of states are considering the merits of various reform proposals. Puig and Shaffer's comprehensive and balanced framework for assessing the tradeoffs involved in making different choices is thus a welcome and timely intervention in these (often highly polarized) debates.

In practice, although the legitimacy of investor-state arbitration has come under fire, states have not (yet) converged on which reforms to pursue. In simplified terms, three main camps have emerged to date:

1. Incrementalists view the criticisms of the current system as overblown and argue that investor-state arbitration remains the best option available. Hence, they favor retaining the existing dispute resolution system but instituting modest reforms that would redress specific concerns.

2. Systemic reformers see merit in retaining investors' ability to file claims directly on the international level, but view investor-state arbitration as a seriously flawed system for dealing with such claims. They champion more significant, systemic reforms, such as replacing investor-state arbitration with a multilateral investment court and an appellate body.

3. Paradigm shifters dismiss the existing system as irrevocably flawed and in need of wholesale replacement. They reject the utility of investors' making international claims against states, whether before arbitral tribunals or international courts. They embrace a variety of alternatives, such as domestic courts, ombudsmen, and state-to-state arbitration. ${ }^{2}$

* School of Regulation and Global Governance (RegNet), Australian National University, Anthea.Roberts@ anu.edu.au. I attend the UNCITRAL Working Group III meetings as a member of the Australian delegation but in my capacity as an independent academic expert. I am also a member of the Academic Group. The views in this essay should not be attributed to the Australian government.

${ }^{1}$ Sergio Puig \& Gregory Shaffer, Imperfect Alternatives: Institutional Choice and the Reform of Investment Law, 112 AJIL 361 (2018).

2 See Anthea Roberts, The Shifting Landscape of Investor-State Arbitration: Loyalists, Reformists, Revolutionaries and Undecideds, EJIL: TALK! (June 15, 2017), at https:/www.ejiltalk.org/the-shifting-landscape-of-investor-statearbitration-loyalists-reformists-revolutionaries-and-undecideds (for the same typology but with different nomenclature). 
Against this backdrop, the United Nations Commission on International Trade Law (UNCITRAL) gave one of its working groups a three-staged mandate to investigate the possible reform of investor-state dispute settlement, which required it, first, to identify and consider concerns about investor-state dispute settlement (ISDS); second, to consider whether reform was desirable in light of any identified concerns; and, third, if reform was desirable, to develop relevant solutions to be recommended to the Commission. ${ }^{3}$ In keeping with the desire of states to retake the reins, the mandate provided that the deliberations would be government-led. ${ }^{4}$ The working group held its first two meetings in 2017 and 2018, and sound recordings were made available online. ${ }^{5}$

This essay complements Puig and Shaffer's comparative institutional framework by (1) conceptualizing the three main reform approaches that have been advocated to date and identifying the likely strategies of, and risks faced by, the different reform champions; and (2) analyzing UNCITRAL's role in these reforms as both a venue for these reform debates and an actor navigating a complex series of relationships with other key stakeholders. Pointing to the future, I conclude by identifying the likelihood of ongoing pluralism with respect to different institutional processes for resolving investment disputes and sketching how actors might proceed to develop flexibility both among and within different reform options. ${ }^{6}$

\section{Three Strategies of Reform}

The bilateral investment treaties (BITs) of major capital-exporting states are commonly divided into first and second generations (BITs 1.0 and 2.0); the former tend to be short and much more protective of investors than state sovereignty, whereas the latter are longer and strike more of a balance between these two objectives. ${ }^{7}$ The 1994 Argentina-United States BIT exemplifies a BIT 1.0, and the 2004 and 2012 U.S. Model BITs are typical of BITs 2.0.8

\footnotetext{
${ }^{3}$ Rep. of the UN Comm'n on Int'l Trade Law of Its Fiftieth Session, at para. 264, UN Doc. A/72/17 (July 21, 2017), available at https://documents-dds-ny.un.org/doc/UNDOC/GEN/V17/058/89/PDF/V1705889.pdf? OpenElement (hereinafter July 21 UNCITRAL Report).

${ }^{4}$ See id.

5 See UN Comm'n on Int'l Trade Law, Working Group III - 2017 to Present: Investor-State Dispute Settlement Reform, at http://www.uncitral.org/uncitral/en/commission/working_groups/3Investor_State.html; UN Comm'n on Int'l Trade Law, Archive of Working Group Audio Recordings, at http://www.uncitral.org/uncitral/audio/meetings.jsp.

${ }^{6}$ This essay draws on publicly available materials; my observations from academic, expert, and intergovernmental meetings, including UNCITRAL; and interviews and discussions with actors in governments, international institutions, the arbitration industry, and nongovernmental organizations. As a participant-observer in these reform processes, I engage with and provide views to a wide range of stakeholders. I have attempted here to faithfully reflect the positions of different stakeholders, though I remain conscious of the impossibility of full neutrality for any participant or observer.

7 See Anthea Roberts, Clash of Paradigms: Actors and Analogies Shaping the Investment Treaty System, 107 AJIL 45, 78-83 (2013).

${ }^{8}$ See Treaty Between the United States of America and the Argentine Republic Concerning the Reciprocal Encouragement and Protection of Investment, Arg.-U.S., Nov. 14, 1991, 31 ILM 124; U.S. Dep't of State, 2004 Model BIT (2004), available at http:/www.state.gov/documents/organization/117601.pdf; Office of U.S. Trade Representative, 2012 U.S. Model Bilateral Investment Treaty, Arts. 24, 37 (2012), available at http://www.ustr.gov/sites/default/files/BIT\%20text\%20for\%20ACIEP\%20Meeting.pdf.
} 
Of course, not all states have followed the same trajectory, China being a case in point. ${ }^{9}$ Since different states take different historical and contemporary approaches to investment treaties, there is no neutral baseline from which to measure reforms. I take the BIT 2.0 model as the starting point for this essay, since many major powers, including the United States and China, have converged toward this model in their recent treaty practice. $^{10}$

Incremental reforms involve adopting small to moderate adjustments to the BIT 2.0 model, something like BITs 2.1, 2.2, and so forth. Systemic reforms operate within the existing system of direct international claims filed by investors against states but involve largerscale or more-structural reforms, tantamount to BITs 3.0. Paradigmatic reform does not amount to creating BITs 4.0 but, rather, shifts to a new framework altogether for resolving foreign investment disputes.

\section{A. Loading the Language, Fixing the Frame}

Before analyzing these different strategies, it is worth pausing to consider issues of language, background, and frame. My typology of incremental to paradigmatic reforms captures the scale of proposed changes, not their merits. Incremental, systemic, and paradigmatic reforms involve progressively more significant departures from the status quo, but that does not mean that more change is necessarily better. To avoid loading the language, I have refrained from using adjectives such as "transformational" and "revolutionary," which may be imbued with positive or pejorative connotations. ${ }^{11}$

In addition, the background paradigm matters because what looks transformational within one paradigm may look traditional within another. For instance, jettisoning investor-state arbitration and reverting to domestic courts and state-to-state arbitration might look transformational within the BIT paradigm, but it is quite traditional when viewed in the broader paradigm of either how investors have been protected historically or how dispute resolution often takes place in other international fields.

Perspective also matters because what looks revolutionary to states operating within one paradigm might represent a continuation of the status quo for states operating within a different paradigm. For example, Brazil never ratified any investment treaties and is now proposing a different model of investment facilitation agreements. Having never adopted the BIT paradigm, Brazil is not seeking to revolt against it. The alternative approach it advocates, however, might be seen as a revolutionary path by states with numerous BIT commitments.

How the issue of choice is framed is also important. Consider possible visual aids that could be used to implicitly communicate different messages about the reform strategies. The triangle in figure 1 , for instance, might bias the reader toward viewing systemic reform as the

${ }^{9}$ See Stephan W. Schill, Tearing Down the Great Wall: The New Generation Investment Treaties of the People's Republic of China, 15 Cardozo J. INT'L \& COMP. L. 73 (2007).

${ }^{10}$ See Axel Berger, Investment Rules in Chinese PTIAs-A Partial "NAFTA-ization," in The Rise of Preferential Trade and InVestment Agreements: Bridging the Gap? 297, 297 (Rainer Hofmann, Stephan Schill \& Christian Tam eds., 2013).

${ }^{11} C f$. the literature on adaptation to climate change, which theorizes three reform strategies: incremental, systemic, and transformative. See L. Rickards \& S.M. Howden, Transformational Adaptation: Agriculture and Climate Change, 63 Crop and Pasture Sci. 240 (2012); Sarah Park, Nadine A. Marshall, Emma Jakku, Anne Marie Dowd, S.M. Howden, Emily Kate Mendham \& A. Fleming, Informing Adaptation Responses to Climate Change Through Theories of Transformation, 22 GLOB. ENVTL. ChANGe 115 (2011). I am grateful to Mark Howden for a presentation that included similar diagrams to the ones that follow. 


\section{Incremental}

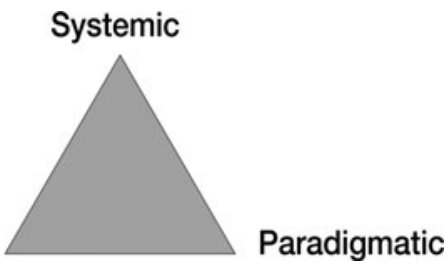

FIGURE 1. In Favor of Systemic Reform as a Sensible Middle Ground Solution

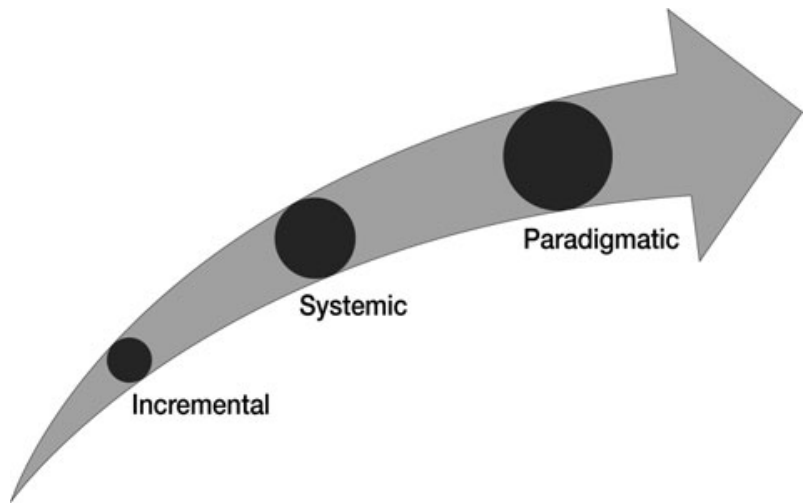

FIGURE 2. In Favor of Onward and Upward Paradigmatic Reforms

privileged (higher) option or the reasonable (midway) point. By contrast, the upward arrow in figure 2 might suggest that the investment treaty system is on a journey that has begun with incremental reforms but will ultimately transition through systemic and then to paradigmatic reform, with an onward and upward momentum.

The sideways arrow in figure 3 might suggest that the most significant changes often come from focusing on smaller-scale but more-achievable incremental reforms, since larger-scale reforms are less likely to be widely adopted and thus ultimately less likely to be effective. In contrast, the circle in figure 4 might suggest that investor-state arbitration amounts to a departure from the traditional approach, but that the progression of incremental, systemic, and paradigmatic reforms ultimately reverts to the traditional approach of domestic courts and state-to-state arbitration.

In my view, incremental, systemic, and paradigmatic reform strategies should not be understood as three points on a spectrum. Actors do not need to try incremental reforms before moving on to the others and they are not obliged to transition through systemic options to adopt paradigm-shifting approaches. Paradigmatic reforms are not necessarily the ultimate endpoint, nor are they always the same as traditional approaches. Instead, these strategies are better conceptualized as three points on a triangle in which actors can move directly from any one to any other point. There is no a priori reason for selecting which point on the triangle should have which label.

These three reform strategies are ideal types, but they are not exhaustive. Actors can adopt intermediate positions between two or more ideal types. For instance, some states might endorse semi-systemic reforms, such as by adopting an incrementally reformed model of investor-state arbitration subject to an appellate body. Or states could adopt semi- 


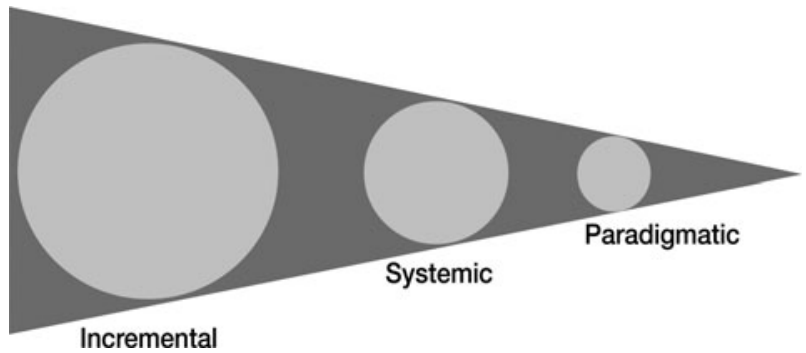

Figure 3. In Favor of Focusing on Achievable and Effective Reforms

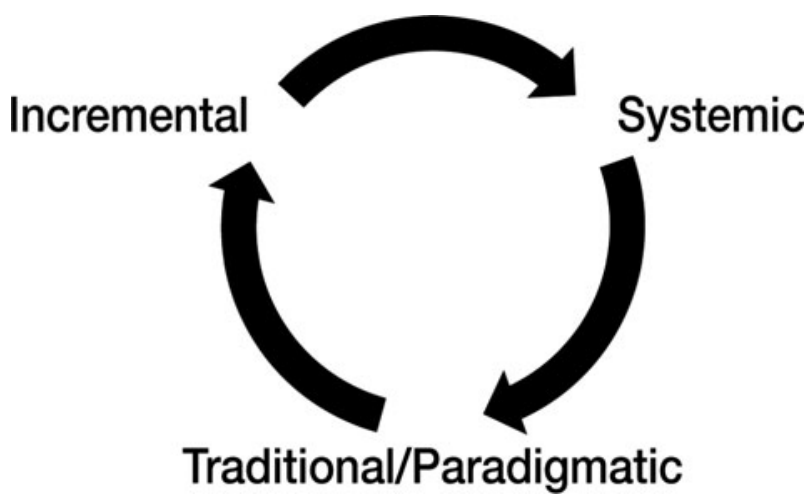

FIgURE 4. In Favor of Focusing on Achievable and Effective Reforms

paradigmatic reforms, as Puig and Shaffer suggest, such as making the availability of international mechanisms subject to exhaustion of domestic remedies.

These reform strategies are not mutually exclusive. Actors may adopt a combination of approaches within or across different treaties, for instance, by endorsing incremental reforms for some treaties and more far-reaching reforms for others. Reform strategies may also impact upon each other. For instance, a realistic possibility of systemic reforms will increase pressure on stakeholders that are resisting change to embrace at least incremental reforms.

\section{B. Identifying Reform Champions}

At UNCITRAL, a wide range of states discussed concerns with investor-state arbitration, as detailed elsewhere. ${ }^{12}$ This section, by contrast, focuses on the handful of states that have taken

\footnotetext{
12 As recordings of the UNCITRAL working group sessions are made available without a transcript, a compilation of relevant quotes, including ones used in this essay, can be found at Anthea Roberts \& Zeineb Bouraoui, UNCITRAL and ISDS Reforms: What are States' Concerns?, EJIL: TALK! (June 5, 2018), at https://www.ejiltalk.org/ uncitral-and-isds-reforms-what-are-states-concerns; Anthea Roberts \& Zeineb Bouraoui, UNCITRAL and ISDS Reforms: Concerns About Consistency, Predictability and Correctness, EJIL: TALK! (June 5, 2018), at https://www. ejiltalk.org/uncitral-and-isds-reforms-concerns-about-consistency-predictability-and-correctness; Anthea Roberts \& Zeineb Bouraoui, UNCITRAL and ISDS Reforms: Concerns About Arbitral Appointments, Incentives and Legitimacy, EJIL: TALK! (June 6, 2018), at https://www.ejiltalk.org/uncitral-and-isds-reforms-concernsabout-arbitral-appointments-incentives-and-legitimacy; Anthea Roberts \& Zeineb Bouraoui, UNCITRAL and ISDS Reforms: Concerns About Costs, Transparency, Third Party Funding and Counterclaims, EJIL: TALK! (June 6, 2018), at https://www.ejiltalk.org/uncitral-and-isds-reforms-concerns-about-costs-transparency-third-partyfunding-and-counterclaims.
} 
positions that are consistent with championing one of the three main reform strategies. This essay takes a snapshot of an evolving process. The positions of states may well shift over time. The UNCITRAL process is also designed to encourage states to reach consensus. Accordingly, one should not view states' current strategies as static.

First, Chile, Japan, and the Russian Federation have taken pro-investor-state arbitration positions that are consistent with incrementalism. The United States and, to a lesser extent, Mexico voiced similar sentiments at the first UNCITRAL working group meeting. But before the second meeting, Mexico agreed to an investment court in its treaty with the European Union, ${ }^{13}$ and U.S. Trade Representative Robert Lighthizer disparaged investor-state arbitration in the context of the North American Free Trade Agreement (NAFTA) negotiations. ${ }^{14}$ Perhaps because of these developments, both states adopted a more muted approach in the second working group meeting.

Incrementalists tend to downplay the severity of the existing system's problems by suggesting, for instance, that the concerns raised are merely matters of perception rather than reality (thus, Chile implored the UNCITRAL working group to fulfill its mandate "based on facts and not perceptions" 15 ), or that the concerns about inconsistent decisions are a natural and positive consequence of the bilateral nature of investment treaties (thus, the Russian Federation argued that the ability of parties to strike particular deals is "an advantage of the system and not a disadvantage" ${ }^{16}$ ).

Incrementalists typically claim that any outstanding problems can be addressed adequately through targeted reforms. For example, the United States noted that problematic or inconsistent interpretations could be rectified by drafting new treaties in more detail or adopting authoritative interpretations. ${ }^{17}$ Incrementalists also warn against enacting systemic reforms that risk undermining some of the key advantages of investor-state arbitration, including neutral appointments, finality, ready enforceability of awards, and depoliticization of disputes. ${ }^{18}$

An ambiguity lies at the heart of the incrementalist camp. Some may be adopting this position for a mix of substantive and/or political reasons, such as a belief that an incrementally improved model, like the Comprehensive and Progressive Agreement for Trans-Pacific Partnership (CPTPP), ${ }^{19}$ provides the best way to handle investor-state disputes or one that has been successfully defended domestically. Others may have genuine concerns about investor-state arbitration, but do not want to be rushed in the UNCITRAL process or railroaded into a court-based model about which they have misgivings.

Certain states have taken a skeptical view of some of the incrementalists' positions, even when the latter have not endorsed any specific reforms. In that vein, Australia argued that

${ }^{13}$ See European Comm'n, New EU-Mexico Agreement: The Agreement in Principle 10-11 (2018), available at http://trade.ec.europa.eu/doclib/docs/2018/april/tradoc_156791.pdf.

${ }^{14}$ See In His Own Words: Lighthizer Lets Loose on Business, Hill Opposition to ISDS, Sunset Clause, WorLd Trade ONLINE (Oct. 19, 2017), at https://insidetrade.com/trade/his-own-words-lighthizer-lets-loose-business-hillopposition-isds-sunset-clause.

${ }^{15}$ Roberts \& Bouraoui, States' Concerns, supra note 12.

${ }^{16}$ Roberts \& Bouraoui, Concerns About Consistency, supra note 12.

${ }^{17} \mathrm{Id}$.

${ }^{18} \mathrm{Id}$.

${ }^{19}$ Comprehensive and Progressive Agreement for Trans-Pacific Partnership (СРTPP), available at http://www. trungtamwto.vn/sites/default/files/comprehensive-and-progressive-agreement-for-trans-pacific-partnershipcptpp-english.pdf. 
both facts and perceptions matter because states have to be concerned with maintaining a "social license" for investor-state dispute settlement: "we are all accountable to the public and we need to [consider] public perceptions to be ... fundamentally relevant to the discussion ...." 20 Other countries, including Mauritius and South Africa, concurred: "Perception matters greatly for it is a basic tenet of the rule of law that justice must not only be done, it must be seen to be done." 21

Second, among those favoring systemic reform, the European Union, Canada, and Mauritius are key advocates. They would retain direct claims by investors against states on the international plane but would replace investor-state arbitration with a multilateral investment court and an appellate mechanism. These actors stress that problems like inconsistent and unpredictable treaty interpretations, and legitimacy concerns stemming from ad hoc arbitral appointments, are serious and systemic and cannot be adequately addressed through incremental changes.

For instance, the European Union argued that investment claims are based on public international law treaties and involve public law disputes in which generally worded constitutional-like clauses are applied to regulate the sovereign actions of states vis-à-vis investors. ${ }^{22}$ In similar areas of law, states have favored the establishment of permanent bodies with full-time, tenured adjudicators, such as the WTO Appellate Body and the European Court of Human Rights. ${ }^{23}$ By contrast, the ad hoc nature of investor-state arbitration raises significant concerns, including a lack of predictability and consistency, limited error correction, concerns over appointments, and costs. ${ }^{24}$

Many other states registered legitimacy concerns arising from inconsistent awards and perceptions of the existence of pro-investor and pro-state arbitrators, which they tied to the ad hoc nature of the system. ${ }^{25}$ Some states emphasized the need for systemic solutions: Argentina stated that the reforms require a "systemic" and "multilateral" approach"; China stressed the need for "integral" and "comprehensive" solutions to "systematic" problems it raised; Kenya called for "holistic" not "piecemeal" reforms; and Algeria advocated "indepth" rather than "frivolous" changes. ${ }^{26}$ A handful seemed to endorse specific solutions, such as Morocco, which stated that "consistency can be assured by the establishment of a multilateral body" made up of a permanent court with an appellate level. ${ }^{27}$

Third, other states, most notably Brazil and South Africa, reject the legitimacy and utility of direct international claims by foreign investors against states, regardless if heard by arbitral tribunals or courts. Brazil explained that it had never ratified investment treaties because of concerns such as that investor-state arbitration imposes "discriminat[ion] against national investors who do not have the chance to resort to international arbitration and must tackle

${ }^{20}$ Roberts \& Bouraoui, States' Concerns, supra note 12.

${ }^{21}$ Id. Mauritius; see also South Africa and Austria.

22 See UN Comm'n on Int'l Trade Law, Possible Reform of Investor-State Dispute Settlement (ISDS), Submission from the European Union, at 2-3, UN Doc. A/CN.9/WG.III/WP.145 (Dec. 12, 2017), available at https://documents-dds-ny.un.org/doc/UNDOC/LTD/V17/088/32/PDF/V1708832.pdf?OpenElement.

${ }^{23}$ See id. at $3-5$.

${ }^{24}$ See id. at $7-12$.

${ }^{25}$ Roberts \& Bouraoui, Concerns About Consistency, supra note 12 (e.g., Egypt, France, Germany, Greece, Singapore, Spain, Thailand, and Uruguay); Roberts \& Bouraoui, Concerns About Arbitrators, supra note 12 (e.g., Argentina, Australia, China, Colombia, Ecuador, and India).

${ }^{26}$ Roberts \& Bouraoui, States' Concerns, supra note 12.

${ }^{27}$ Roberts \& Bouraoui, Concerns About Consistency, supra note 12. 
any issues within the domestic courts." 28 Similarly, South Africa decried the "exorbitant costs" for cases paid out of public budgets and noted that " $[\mathrm{d}]$ omestic investors cannot initiate an ISDS dispute [as this] is a privilege for foreign investors only, which raises the question of equal access to justice." 29

To these states, incremental and systemic reforms will never suffice to redress the system's problems - a paradigm shift is required. According to Brazil: "ISDS is intrinsically flawed. No reforms would be enough to redeem the system .... For us the best solution is simply throw it out of the window and use something different. And we use SSDS, state to state dispute settlement." 30 A Brazilian investment treaty policymaker elaborated:

Investment treaties are much like pre-nuptial agreements where a couple agrees to get married but is already looking ahead to the terms on which a divorce might happen. After that divorce, each party goes its separate way and is not to be seen again. I prefer to think of Brazil's investment facilitation approach as more akin to couple's counselling because we are trying to facilitate a long-term relationship that remains positive rather than envisaging a future divorce. It's a completely different approach. ${ }^{31}$

South Africa likewise argued that reforms must not simply "legitimize the current system ... without any meaningful transformational results." 32 Any new mechanism must take public policy issues into account and permit much broader stakeholder participation, including by permitting standing for actors other than investors and states. ${ }^{33}$

Paradigm shifting countries thus favor replacing international claims between investors and states with alternatives. South Africa recently terminated most of its investment treaties and replaced them with domestic legislation permitting foreign investors to litigate in its domestic courts or bring mediation claims against the government. If a dispute persists, South Africa may later consent to state-to-state arbitration. Brazil has championed "investment facilitation" agreements where an ombudsman is given powers to try to resolve disputes involving foreign investors. If the dispute persists, the treaty parties consent in advance to state-to-state arbitration.

It is uncertain, however, whether Brazil or South Africa will champion these approaches in UNCITRAL. The paradigm-shifters are more united by what they stand against (the current system) than what they stand for (as they embrace a variety of alternatives). Currently, they do not appear to be coordinating to establish an integrated rival strategy.

Because these three strategies represent ideal types, not all states fit neatly within a single camp. For instance, India's 2015 Model BIT accepts investor-state arbitration but conditions it on extensive resort to domestic remedies and indicates an openness to a future appellate mechanism. ${ }^{34}$ Although India has not thus far strongly advocated its model in

${ }^{28}$ Roberts \& Bouraoui, States' Concerns, supra note 12.

${ }^{29}$ Roberts \& Bouraoui, Concerns About Costs, supra note 12.

30 Roberts \& Bouraoui, States' Concerns, supra note 12.

${ }^{31}$ Interview, Brazilian Investment Treaty Policy Maker (May 5, 2018) (on file with author).

${ }^{32}$ Recording: United Nations Comm'n. on Int'l Trade Law, 50th Sess. (July 10, 2017), available at https:// icms.unov.org/CarbonWeb/public/uncitral/speakerslog/1b00d406-0d09-4dec-alab-74cf6dcf8428 (hereinafter July 10 UN Meeting Recording).

${ }^{33} \mathrm{Id}$.

${ }^{34}$ Government of India, Ministry of Finance, Model Text for the Indian Bilateral Investment Treaty, available at http://investmentpolicyhub.unctad.org/Download/TreatyFile/3560. 
UNCITRAL, its approach arguably comes the closest to modeling the semi-paradigmatic reforms supported by Puig and Shaffer, whereby any international institutional mechanism—whether an international court or arbitral tribunal—may be offered as a complement to, rather than a substitute for, domestic courts, and hence as a means to strengthen the domestic rule of law.

One question to consider is why a core constituency of states has not evolved around this option. States with strong interests as capital-exporters may be reluctant to empower domestic courts in certain developing states owing to concerns about the quality and timeliness of the justice they dispense. As regards incoming investments, these states may have faith in their own domestic courts but hesitate to set up a structure in which international tribunals routinely pass judgment on the decisions of their highest courts (as this prospect may exacerbate, rather than quell, populist concerns). States that are strong capital-importers, in contrast, may lack the capacity and bargaining power to back this approach. Others may feel confident enough to assert the jurisdiction of their courts but lack the inclination to make these courts subject to international oversight.

Beyond states, various international organizations, arbitral institutions, and nonstate actors (including nongovernmental organizations (NGOs), academics, and arbitration practitioners) are aligning themselves with one or another strategy. Although no community of actors is uniform, arbitration practitioners often line up behind the incrementalist position, whereas NGOs frequently call for paradigmatic reforms. Others, like the International Centre for Settlement of Investment Disputes (ICSID), are assuming a nuanced posture, driving incremental reforms while remaining supportive of systemic changes. ${ }^{35}$

\section{Strategies and Risks}

Identifying the strategies and risks of different reform advocates requires assessing their best to worst options in isolation, as well as their perceptions of which option is most likely to succeed at any particular moment. The latter point is important because actors assess their options both dynamically and, as Puig and Shaffer indicate, comparatively. An actor might decide that it is rational to embrace its second-best option if it thinks its best option is unachievable and there is a genuine risk that if it does not compromise, it will be faced with its worst option. The likely approaches of key states that have yet to declare a position is another relevant consideration.

\section{Incrementalists}

The incrementalists count many powerful actors among their number, including significant capital exporters and many arbitration practitioners. They enjoy the benefit of the status quo and can effectively stall or slow down any multilateral reform efforts. Nonetheless, they must contend with three key weaknesses: their supporters do not include all major capital exporters/importers or primarily capital-importing states; the current system has become very controversial; and the ongoing commitment of at least one key proponent of incrementalism (the United States) is uncertain.

\footnotetext{
35 See Meg Kinnear, Secretary-General, Int'l Ctr. for Settlement of Inv. Disputes, 2018 Charles N. Brower Lecture on International Dispute Resolution: Policy and Progress: Seeking Consensus in ISDS Rules Reform at the ASIL Annual Meeting (Apr. 6, 2018).
} 
A significant risk the incrementalists face is that by refusing to bend (that is, to countenance systemic reform in response to widespread discontent), they will exacerbate the chance that the system will break (that is, that states will abandon the system altogether). Given growing discontent with ISDS, the incrementalists cannot assume that the status quo is stable, particularly if the United States were to clearly withdraw its support for the existing system. The United States' current rhetoric is more supportive of paradigmatic reform than incrementalism or systemic reform. ${ }^{36}$

Some incrementalists, including certain states and the arbitration industry, may not incline toward a permanent court in comparison with arbitration but are likely to prefer it vastly to the inability of investors to bring direct claims before international tribunals. If systemic reform comes to seem inevitable, these incrementalists will also have an incentive to engage more actively with the process in an effort to shape it. Thus, we should expect some incrementalists to modify their hostile stance toward systemic reforms if the risk of paradigmatic reform starts to feel possible or systemic reform appears inevitable.

Arbitral institutions typically occupy a place between supporting incremental and systemic reform. They have an interest in maintaining the existence and legitimacy of the system and preserving or improving their market share. This interest helps explain why ICSID, for instance, is engaged in improving its rules; ${ }^{37}$ in so doing, it both embraces incremental reform and incidentally lessens the case for systemic or paradigmatic reform for states that might be sitting on the fence. But ICSID also appears open to working with the systemic reformers on becoming a host institution for future investment courts, ${ }^{38}$ which would assist in ensuring that, if systemic reform transpires, it would be well placed to retain or augment its caseload rather than lose out to new or existing competitors.

\section{Systemic reformers}

The systemic reformers do not enjoy the inertia of the default bias, so they have to rally states in support of a new direction. They also need to build an international coalition because they cannot give effect to their reforms unilaterally. Such an endeavor is difficult because collective innovation-decisions are typically slower to be adopted than either "optional innovation-decisions" (which actors can choose to adopt or reject individually) or "authority innovation-decisions" (where decisions on adoption are made by a centralized authority and mandated for others). ${ }^{39}$ Even if a collective decision to draft a statute for a multilateral

${ }^{36}$ Despite the 2004 U.S. Model BIT suggesting an interest in working toward an appellate body, the 2012 U.S. Model BIT walked back from that position. Compare 2004 U.S. Model BIT, Article 28.10 and Annex D with 2012 U.S. Model BIT, Article 28.10. Given its previous history with international courts, and its current position with respect to the World Trade Organization's Appellate Body, it seems unlikely that the United States would have the domestic constituency to support an investment court or appellate mechanism.

37 See Amendment of ICSID's Rules and Regulations, INT'L CTR. FOR SETTLEMENT OF INV. Disputes, at https://icsid. worldbank.org/en/Pages/about/Amendment-of-ICSID-Rules-and-Regulations.aspx.

${ }^{38}$ For example, ICSID will act as the Secretariat for the investment courts contemplated in the EU's agreements with Canada and Singapore. See European Comm'n, Comprehensive Economic and Trade Agreement (CETA) Between Canada, of the One Part, and the European Union, Art. 8.27.16 (1994), available at http://trade.ec. europa.eu/doclib/docs/2014/september/tradoc_152806.pdf; European Comm'n, Chapter Three Dispute Settlement, Art. 3.9.16 (2018), available at http://trade.ec.europa.eu/doclib/docs/2018/april/tradoc_156731.pdf.

39 Everett M. Rogers, Diffusion of Innovations 403 (5th ed. 2003). 
investment court is made, states would then have the individual option of whether or not to embrace that innovation.

Systemic reformers are attempting to sell their position as a sensible, middle-ground option that responds to significant concerns about the system's legitimacy without throwing the baby out with the bathwater. Unfortunately, their posture looks like too much reform to some, but too little to others.

Systemic reformers also face the problem of "horizontal hostility." 40 Movements in favor of a cause often attract both moderate and radical subgroups. Instead of the groups being bound together by the common cause, the radical group frequently proves its commitment to the cause partly by distancing itself from the moderate group. ${ }^{41}$ For instance, vegans show three times as much prejudice toward vegetarians as the other way around. ${ }^{42}$ In this situation, strong critics of the system are often particularly hostile toward those seeking to reform, rather than overthrow, the system. That attitude makes it harder for the systemic reformers to bring the paradigmatic reformers on board.

The horizontal hostility problem is manifest in the reaction of some NGOs to the European Union's proposal for a multilateral investment court. S2B, the Seattle to Brussels Network that arose after the 1999 WTO protests in Seattle to challenge what they view as the corporate-driven trade agenda of the European Union, argued that the EU proposal is a "thinly veiled effort to salvage the failing investor-state dispute settlement system by replacing it with a rebranded twin" in order to "enshrine and expand the current system of corporate privilege." 43 Similarly, the Columbia Center for Sustainable Investment declared that the proposed court "fall[s] dramatically short in addressing the most problematic aspects of the ISDS regime and in fact would serve to further expand and entrench the controversial ISDS mechanism." 44

On the other side, many members of the arbitral community are also highly critical, viewing the court proposal as more of an attack on arbitration than a savior of investor protection, and criticizing it for being "remarkably divorced from reality." 45 For instance, a prominent arbitrator, Judge Stephen M. Schwebel, explained that his "fundamental objection" to the European Union's proposal is that it would replace a system that "on any objective analysis works reasonably well" with "a system that would face substantial problems of coherence, rationalization, negotiation, ratification, establishment, functioning and financing." 46

\footnotetext{
${ }^{40}$ Judith B. White \& Ellen J. Langer, Horizontal Hostility: Relations Between Similar Minority Groups, 55 J. Soc. Issues 537 (1999); Judith B. White, Michael T. Schmitt \& Ellen J. Langer, Horizontal Hostility: Multiple Minority Groups and Differentiation from the Mainstream, 9 Group Processes \& INTERgroup Rel. 339 (2006).

${ }^{41}$ See Adam Grant, Originals: How Non-conformists Move the World 117-22 (2016).

${ }^{4}$ Id. at 118 n. 41.

${ }^{43}$ Rosa-Luxemburg-Stiftung, A World Court for Corporations: How the EU Plans to Entrench and Institutionalize Investor-State Dispute Settlement 3 (2017), available at http://www.s2bnetwork.org/wpcontent/uploads/2017/12/WORLDCOURT-UK-www.pdf.

${ }^{44}$ Columbia Ctr. on Sustainable Inv., Position Paper in Support of Opinions Expressed in Response to the European Commission's "Public Consultation on a Multilateral Reform of Investment Dispute" Resolution 1 (2017), available at http://isdsblog.com/wp-content/uploads/sites/2/2016/05/THEPROPOSALSOFTHEEUROPEANCOMMISSION. pdf.

${ }^{45}$ Anne-Karin Grill, Mind the Label: Loyalists and Reformists and ISDS, KLUWER ARB. Blog (Dec. 29, 2017), at http://arbitrationblog.kluwerarbitration.com/2017/12/29/uncitral-isds-working-group-vienna-11-12-2017.

46 Judge Stephen Schwebel, Remarks at Sidley Austin (May 17, 2016) (transcript available at http://isdsblog. com/wpcontent/uploads/sites/2/2016/05/THEPROPOSALSOFTHEEUROPEANCOMMISSION.pdf).
} 
As studies of diffusion have shown, for a proposed innovation to attain a critical mass, it is essential for a number of early adopters to become opinion leaders that preach the virtue of the new approach. ${ }^{47}$ The innovator here, the European Union, commands two mechanisms to generate support for its new approach: power and persuasion. The EU has used its negotiating power to gain agreement on bilateral investment courts with several of its treaty partners, including Canada, Mexico, Singapore, and Vietnam. Other than Canada, however, these states have not become vocal proponents of the new system, at least to date, though they may partly be waiting for the dust to settle with respect to the EU's internal legal competence.

If the European Union is able to transmit this innovation to its treaty partners only based on its power, the best it will end up with is a plurilateral investment court comprising it and those partners. ${ }^{48}$ For such a court to become truly multinational, the European Union needs to persuade some other key opinion leaders to champion the institution and advance it through their own treaty practices. This process could include favorably disposed states that have not concluded a recent treaty with the European Union, such as Morocco and Mauritius. The UNCITRAL reform debates give the European Union a platform from which to advocate for its proposal multilaterally.

A significant aspect of diffusion involves identifying opinion leaders from diverse backgrounds, as their participation enhances the likelihood of diffusion. Such transfers often occur between actors that are like each other in key ways. ${ }^{49}$ It is no surprise, then, that the innovation first spread from the European Union to Canada. To take hold multilaterally, however, opinion leaders should be engaged that are different from these states in key ways and more similar to other states from diverse regions or with diverse profiles. Thus, Singapore or Korea might be influential in establishing support for this innovation in Asia if they became opinion leaders, as might Argentina or Mexico in Latin America, or Morocco or Mauritius in Africa.

The investment court and appellate body proposal will not become a "movement" unless and until it moves without the European Union. ${ }^{50}$ If the systemic reformers do not succeed in getting a critical mass of states on board with their proposal, they risk creating an even more fragmented system.

\section{Paradigmatic reformers}

Paradigmatic reformers do not benefit from a status quo bias and they need to develop a greater appetite for reform than the systemic reformers because of the degree of change they favor. Still, unlike the systemic reformers, the paradigmatic reformers often have the advantage of proposing approaches that do not require collective agreement. States can decide individually to withdraw from their investment treaties and pursue other options. Doing so en masse helps to reduce any stigma and potential (or perceived) loss of competitiveness associated with such moves, but it is not essential, as is a degree of multilateral coordination for the

\footnotetext{
${ }^{47}$ Rogers, supra note 39, at 343-52.

${ }^{48}$ Anthea Roberts, UNCITRAL and ISDS Reform: Pluralism and the Plurilateral Investment Court, EJIL: TALK', (Dec. 12, 2017), at https://www.ejiltalk.org/uncitral-and-isds-reform-pluralism-and-the-plurilateral-investmentcourt.

${ }^{49}$ Rogers, supra note 39, at 306-08.

${ }^{50}$ Cf. Jeremy Heimans \& Henry Timms, New Power 47, 62 (2018).
} 
court proposal. Entering into new treaties requires collective agreement but passing legislation does not.

The biggest quandary for paradigmatic reform champions concerns whether to support reforms that are more moderate than their ideal preference. States like South Africa, ${ }^{51}$ along with many NGOs, identify both procedural and substantive problems with the system that they believe require a fundamental overhaul. Should they support the procedural reforms pushed by the systemic reformers, which go partway to addressing their concerns, knowing that, if they do, this route might neutralize some of those problems with the system in a way that reinforces its existence and undermines the likelihood of more revolutionary reforms?

Their answer to this dilemma likely depends on two factors: how much they consider the problems to be primarily ones of substance or procedure, and how strongly they assess the prospects of paradigmatic reform. If they locate the problems at a more substantive level, they are more likely to conclude that procedural reforms alone would be insufficient and vice versa. (The systemic reformists, of course, argue that fixing the process will help prevent problematic interpretations of substantive obligations.) If paradigmatic reform seems unlikely at least any time soon, systemic reform might seem like a wise option.

\section{Yet-to-declare states}

A majority of states are playing a wait-and-see game for now, taking time to consider the issues and formulate their approaches. Many states that remain in the "undecided" camp probably view themselves as price-takers rather than price-makers, which gives them an incentive to remain open to different approaches so that they have the flexibility to adopt one set of reforms in treaties with one powerful actor and another with a different powerful actor.

That characterization does not, however, hold true for China, which has a marked potential to be a price-maker in its treaty negotiations and to lend crucial weight to one or more of the reform strategies. This conclusion is reinforced by China's need to upgrade its investment treaties with Belt and Road Initiative states. ${ }^{52}$ Although China maintains investment treaties with most of these states, most of them are early generation investment treaties that provide for limited protections and restricted recourse to arbitration. China is likely to seek to upgrade these treaties, though it has also announced its plans to adopt other mechanisms along this route, such as new institutions to deal with commercial disputes. ${ }^{53}$

China could well become a semi-systemic reformer, seeking to retain investment treaty arbitration with incremental improvements but subject to an appellate body. The Chinese experience with the WTO Appellate Body has been positive. China has benefited from being able to know and work with a fairly consistent and predictable body of jurisprudence. It has developed a cadre of international lawyers in government and private practice that are

${ }^{51}$ July 10 UN Meeting Recording, supra note 32.

52 Peter Cai, Understanding China's Belt and Road Initiative, Lowy Inst. INT'L Pol'y (Mar. 2017), available at https://www.lowyinstitute.org/sites/default/files/documents/Understanding\%20China\%E2\%80\%99s\%20Belt \%20and\%20Road\%20Initiative_WEB_1.pdf.

${ }^{53}$ Jerome A. Cohen, The Belt and Road Initiative (BRI) Courts? China's Attitude Towards Dispute Resolution, JERRY's BLOG (Feb. 19, 2018), at http://www.jeromecohen.net/jerrys-blog/the-bri-courts. 
used to dealing with WTO disputes and are now also engaged on investment treaty issues. ${ }^{54} \mathrm{~A}$ Chinese judge would be likely to be appointed to any new institution, whereas the nation is seriously underrepresented in terms of the appointment of its nationals as arbitrators. Yet China may well be hesitant about totally replacing investor arbitration given its typically cautious and incremental approach to international lawmaking and adjudication.

At UNCITRAL, China has expressed concern that the existing corrective mechanisms (annulment and judicial review) were "limited" when it came to ensuring the important values of consistency and correctness. ${ }^{55}$ Such mechanisms not only did not guarantee predictability and certainty, but sometimes made the situation worse. Moreover, the system's current corrective mechanisms were "defective" and did not provide a "systematic and effective ... institutionalized correction arrangement." 56 China thus recommended that UNCITRAL study how to ensure the availability of an effective corrective mechanism, including by looking at whether a "new correction mechanism" should be adopted and, if so, how it should be constructed. ${ }^{57}$

In addition, China stressed that the "fundamental difference" between investment and commercial arbitration was that the former deals with the government, whereas the latter concerns private rights only. ${ }^{58}$ China worried that international commercial arbitrators might lack an understanding of how governments operate. Investment arbitrators do not need to be "pro-government," China indicated, pointing to its own dual interests as a capital importer and exporter. Rather, they must "protect the legitimate rights and interests of investors in strict compliance with treaties." 59 China therefore concluded that investment arbitrators should be required to have a "background in public international law or legal knowledge regarding investment treaties." 60

\section{UNCITRAL AS A VENUE AND AN ACTOR}

In addition to states, many other international organizations, NGOs, academics, and arbitrators are also weighing in on these debates. The most significant nonstate actor that should be analyzed, however, is probably UNCITRAL itself. UNCITRAL is a venue for international lawmaking, but it should also be understood as an actor that has navigated a complex series of relationships in hopes of forging a salient role for the organization in the reform process.

\section{A. UNCITRAL as Lawmaker and Agenda Setter}

UNCITRAL was established by the United Nations General Assembly in 1966 with a mandate to progressively harmonize and modernize international trade law. ${ }^{61}$ The UNCITRAL

\footnotetext{
${ }^{54}$ Gregory Shaffer \& Henry S. Gao, China's Rise: How It Took on the U.S. at the WTO, 2018(1) U. ILL. L. REV. 115,157 (2018).

${ }^{55}$ Roberts \& Bouraoui, Concerns About Consistency, supra note 12.

${ }^{56} I d$.

${ }^{57} \mathrm{Id}$.

${ }^{58}$ Roberts \& Bouraoui, Concerns About Arbitrators, supra note 12.

${ }^{59} \mathrm{Id}$.

${ }^{60} \mathrm{Id}$. Similar qualification requirements exist in the EU's court model in its agreements with Canada and Singapore. See supra note 38, Art. 8.27(4) (Canada); Art. 3.9(4) (Singapore).

${ }^{61}$ GA Res. 2205 (XXI) (Dec. 17 1966), available at https://documents-dds-ny.un.org/doc/RESOLUTION/ GEN/NR0/005/08/IMG/NR000508.pdf?OpenElement.
} 
Commission is made up of sixty states, elected by the General Assembly. The Commission grants mandates on particular topics to working groups, which are made up of the UNCITRAL member states. Other states, as well as intergovernmental and non-governmental organizations, can attend working group and Commission sessions as observers. UNCITRAL also has a Secretariat, which prepares working papers, provides administrative support, and reports on working group sessions. ${ }^{62}$

As an international organization striving for legitimacy and resources in a world of scarcity, UNCITRAL's Secretariat actively scouts promising new topic areas for work. The organization has crafted a central role for itself in international lawmaking through (1) its claim to inclusive procedural legitimacy, because it serves as a forum for bringing together all states and integrating key nonstate actors into its proceedings; (2) its use of a variety of legal instruments from "hard" treaties to "soft" model laws and nonbinding rules, to give it flexibility in tackling subjects of variable difficulty and to enable differently situated states to use its products; and (3) its success in bringing potential competitors into cooperative roles within its own lawmaking processes. ${ }^{63}$

UNCITRAL had traditionally been active in international arbitration by, for instance, drafting arbitration rules that are used in both commercial and investment arbitration. It has a practice of incrementally increasing its lawmaking scope by starting in core areas and then expanding its jurisdiction horizontally (to cover new fields, including banking and finance) and vertically (working from softer to harder legal instruments). ${ }^{64}$ It did so in this context by starting to deal with investment treaty arbitration separately from commercial arbitration, becoming the forum for negotiating the soft UNCITRAL Rules on Transparency in Treaty-Based Investor-State Arbitration (the Transparency Rules), followed by the hard United Nations Convention on Transparency in Treaty-Based Investor-State Arbitration (the Mauritius Convention). ${ }^{65}$

UNCITRAL frequently practices "pyramidal incrementalism," where it sets out to cover new topics by standing on the shoulders of work previously completed by itself or other intergovernmental organizations. ${ }^{66}$ The Mauritius Convention represented a new and flexible instrument permitting multilateral reform of thousands of bilateral agreements by allowing states to decide individually whether to opt in or opt out regarding their existing and new investment treaties. A similar mechanism had been adopted by the Organisation for Economic Co-operation and Development (OECD) regarding the reform of tax treaties. ${ }^{67}$

${ }^{62}$ See generally UN Comm'n. on Int'l Trade Law, A Guide to UNCITRAL: Basic Facts About the United Nations Commission on International Trade Law, available at http://www.uncitral.org/pdf/english/texts/ general/12-57491-Guide-to-UNCITRAL-e.pdf.

${ }^{63}$ Susan Block-Lieb \& Terence C. Halliday, Global Lawmakers: International Organizations in the Crafting of World Markets 12, 38-40, 72-73, 80-82, 156, 257 (2017).

${ }^{64} \mathrm{Id}$. at 83-84, 89, 156, 227-35.

65 UN Comm'n on Int'l Trade Law, United Nations Convention on Transparency in Treaty-based InvestorState Arbitration (Feb. 2015), available at https://www.uncitral.org/pdf/english/texts/arbitration/transparencyconvention/Transparency-Convention-e.pdf; UN Comm'n on Int'l Trade Law, UNCITRAL Rules on Transparency in Treaty-based Investor-State Arbitration (Jan. 2014), available at https://www.uncitral.org/pdf/ english/texts/arbitration/rules-on-transparency/Rules-on-Transparency-E.pdf.

${ }^{66}$ Block-Lieb \& Halliday, supra note 63, at 83-85, 262.

${ }^{67}$ Multilateral Convention to Implement Tax Treaty Related Measures to Prevent Base Erosion and Profit Shifting, June 7, 2017, OECD, at http://www.oecd.org/tax/treaties/multilateral-convention-to-implement-taxtreaty-related-measures-to-prevent-beps.htm. 
Leveraging these successes, UNCITRAL's Secretariat turned its attention to whether the Mauritius Convention could serve as a model for more ambitious reforms.

\section{B. Cooperation and Competition}

To be successful in securing a mandate on this topic, UNCITRAL had to cooperate with actors that could further its agenda while coopting possible competitors and diffusing potential opponents. Such strategizing accords with UNCITRAL's historical approach of collaborating with at least one powerful state and one influential nonstate actor. ${ }^{68}$

In terms of cooperation, UNCITRAL's Secretariat, with the approval of the Commission, began by commissioning the Center for International Dispute Settlement (CIDS), a Genevabased research center, to write a report. The CIDS report was written by Gabrielle KaufmannKohler (a professor and the most frequently appointed investment arbitrator in the world) and Michele Potestà (a senior researcher at CIDS and an arbitration practitioner) who, like many in the field, are amphibious academic-practitioners. ${ }^{69}$ The report, which was extremely well done, was more detailed and specific than had originally been intended, and focused on whether the Mauritius Convention could be used to introduce an investment court or appeal mechanism.

The CIDS report was a catalyst in the reform process, setting the stage for reform debates and solidifying UNCITRAL's claim to be the venue in which these debates should occur. It also raised disquiet in some corners, however, about whether UNCITRAL's Secretariat was pushing a particular reform agenda.

As a potential forum, UNCITRAL faced competition from other international organizations, most notably the United Nations Conference on Trade and Development (UNCTAD) and the OECD, both of which had long histories in the investment treaty field. Yet neither constituted an obvious institutional home for debates about investorstate arbitration reform. In private, some states discounted UNCTAD as too close to the developing world and as a "talking shop" rather than a negotiating or lawmaking forum. Others viewed the OECD as having been insufficiently inclusive in its membership and too closely aligned with the developed world and having lost some credibility as a forum for negotiating investment issues after the failed Multilateral Agreement on Investment in the 1990s.

Nevertheless, one issue raised about moving forward in UNCITRAL was the perception that the arbitration industry had a vested interest in maintaining the status quo and that the forum was dominated by practitioners. For some states, this view was exacerbated by the practitioner pedigree of the CIDS report's authors. Arbitration has typically been covered by Working Group II and, because these matters have historically been viewed as technical and not highly political, many states have been represented in that group by arbitration practitioners. Some states and academics thus worried that entrusting the arbitration reforms to UNCITRAL was akin to putting the fox in charge of the henhouse. ${ }^{70}$

\footnotetext{
${ }^{68}$ See Block-Lieb \& HallidaY, supra note 63; see also examples at 108-09, 120, 147, 200, 377.

${ }^{69}$ Gabrielle Kaufmann-Kohler \& Michele Potestà, Can the Mauritius Convention Serve as a Model for the Reform of Investor-State Arbitration in Connection with the Introduction of a Permanent Investment Tribunal or an Appeal Mechanism?, CIDS - Geneva CTR. InT'L Disp. Settlement (2016), available at http://www.uncitral.org/pdf/ english/CIDS_Research_Paper_Mauritius.pdf.

${ }^{70}$ Anthea Roberts, UNCITRAL and ISDS Reform: Not Business as Usual, EJIL: TALK! (Dec. 11, 2017), at https:// www.ejiltalk.org/uncitral-and-isds-reform-not-business-as-usual; Grill, supra note 45.
} 
To move forward, UNCITRAL also had to shift the European Union from a position of competition to cooperation. At its 2016 Commission meeting, UNCITRAL's initiative did not receive a positive response from the European Union. ${ }^{71}$ Together with Canada, the European Union had been considering launching its own push for a multilateral investment court, though it had yet to announce that plan publicly. ${ }^{72}$ These states cohosted an initial intergovernmental expert meeting on the court. ${ }^{73}$ However, after a series of formal meetings and informal discussions, ${ }^{74}$ they ultimately accepted the merit of working within UNCITRAL given the organization's significant convening power and that its perceived responsiveness to the concern raised by a number of states about practitioner dominance. ${ }^{75}$

Yet UNCITRAL still faced opposition. At its 2017 Commission meeting, the United States and Japan opposed granting the requisite mandate. They viewed multilateral reforms as unnecessary and worried that the process would be used to railroad states into accepting a multilateral investment court. The two states also harbored an unspoken concern that UNCITRAL was a disadvantageous forum for them, as the European Union could count on multiple member states in UNCITRAL, as well as its own role as an observer. Europe could thus play a strong role in debates and would be well placed to push through its agenda if any issues came to a vote instead of being agreed on by consensus.

In an effort to diffuse concerns, the European Union and Canada "poured water into their wine," 76 stressing that an initial decision to consider reform was separate from any later decision in favor of a court. A wide range of states from many parts of the world favored granting a mandate in order to have a forum for multilateral discussions on investor-state arbitration reform, even if they did not necessarily support the proposal for a multilateral investment court. This ultimately led to the sequenced mandate whereby states would first identify their concerns, then consider the desirability of reform, and finally consider relevant solutions to be recommended, without any mention of particular reform options.

To manage concerns that practitioners dominated UNCITRAL, the mandate was granted to Working Group III and specified that "the deliberations, while benefiting from the widest possible breadth of available expertise from all stakeholders, would be Government-led with

\footnotetext{
${ }^{71}$ Recording: United Nations Comm'n. on Int'l Trade Law, 49th Sess. (July 8, 2016), available at https://icms. unov.org/CarbonWeb/public/uncitral/speakerslog/56d8ad62-9089-469b-b0a1-573dce6136da.

72 This announcement was made in October 2017. See Gen. Secretariat of the Council of the EU, Joint Interpretative Instrument on the Comprehensive Economic and Trade Agreement (CETA) Between Canada and the European Union and its Member States, EU Doc. 13541/16, \$ 6(i) (Oct. 27, 2016), at https://eur-lex. europa.eu/legal-content/EN/TXT/?toc=OJ:L:2017:011:FULL\&uri=uriserv:OJ.L_.2017.011.01.0003.01.ENG.

${ }^{73}$ Eur. Comm'n Directorate General for Trade, Government of Canada, Discussion Paper: Establishment of a Multilateral Investment Dispute Settlement System (Dec. 14, 2016), available at http://trade.ec.europa.eu/ doclib/docs/2017/january/tradoc_155267.12.12\%20With\%20date_\%20Discussion\%20paper_Establishment $\% 20$ of\%20a\%20multilateral\%20investment $\% 20$ Geneva.pdf.

74 See, e.g., UNCITRAL-CIDS Government Experts Meeting, Geneva CTr. InT'L Disp. Settlement (Mar. 2, 2018), at http://www.cids.ch/events/uncitral-cids-government-experts-meeting.

${ }^{75}$ Interview, European Commission Official (May 21, 2018) (on file with author).

${ }^{76}$ Interview, Staff Member of an International Arbitral Institution (May 28, 2018) (on file with author) (discussing the European Union and Canada's attempt to dilute the significance of a decision to move foward). See also text accompanying note 87 infra.
} 
high-level input from all Governments." 77 UNCITRAL was eager to begin work straightaway, particularly as Working Group III was finishing its current project and risked losing its meeting slots in New York and Vienna without a new assignment. The European Union was also keen to start. Although Working Group II had traditionally dealt with arbitration, it would not be free for another year. ${ }^{78}$

States determine who represents them at UNCITRAL and the composition of different working groups has changed over time with respect to different topics. Working Group II enjoyed greater state representation when working on transparency, for instance, than it did when dealing with UNCITRAL's Model Law on International Commercial Arbitration and Arbitration Rules. ${ }^{79}$ To some extent, working groups are empty shells that can be composed of different specialists depending on the subject matter before them. Just because Working Group II had dealt with arbitration topics to date, there was no reason it had to continue to do so. Shifting to Working Group III also made it easier to send government representatives without having to displace existing representatives who are arbitration practitioners.

The government-led nature of the process was immediately palpable and was clearly not "business as usual." ${ }^{80}$ At both working group meetings, states were overwhelmingly represented by government officials. Instead of sending diplomats with little background on the topic, many states selected investment treaty law and policy experts as their representatives. Some private practitioners remained, but only a handful spoke on behalf of their states. Thus, although to date public debates about investment treaties have often been dominated by arbitration practitioners, academics, and NGOs, UNCITRAL clearly transferred power back to states as the masters of their treaties. ${ }^{81}$

\section{Combat and Cooption}

To navigate this process successfully, UNCITRAL must also deal with combative relations with some stakeholders while not allowing itself to be coopted by others.

In terms of combative relations, the mandate provoked a hostile response from some members of the arbitration community. For instance, noted arbitrator Charles Brower identified UNCITRAL as the "biggest enemy" to investor-state arbitration, asking: "Why do these acknowledged leaders of investment dispute arbitration as we know it bring termites into our wooden house of investor state dispute resolution? Why are they putting themselves out there to tear down what made them what they are?" 82 Of the decision to give the mandate

${ }^{77}$ UN Comm'n on Int'l Trade Law, Working Group III, Possible Reform of Investor-State Dispute Settlement (ISDS), para. 3, UN Doc. A/CN.9/WG.III/WP.142 (Sept. 18, 2017), available at https://documents-dds-ny.un. org/doc/UNDOC/LTD/V17/067/48/PDF/V1706748.pdf?OpenElement.

78 July 21 UNCITRAL Report, supra note 3, para. 260.

79 See UN Comm'n on Int'l Trade Law, UNCITRAL Model Law on International Commercial Arbitration (1985), with Amendments as Adopted in 2006, at http://www.uncitral.org/uncitral/en/uncitral_texts/arbitration/1985Model_arbitration.html; UN Comm'n on Int'l Trade Law, UNCITRAL Arbitration Rules, at http:// www.uncitral.org/uncitral/en/uncitral_texts/arbitration/2010Arbitration_rules.html.

${ }^{80}$ Roberts, UNCITRAL and ISDS Reform, supra note 70.

${ }^{81}$ See Anthea Roberts, Power and Persuasion in Investment Treaty Interpretation: The Dual Role of States, 104 AJIL 179, 189-91, 202 (2010).

${ }^{82}$ Lindsey Pelucacci, Hon. Charles N. Brower Delivers Keynote Address at International Arbitration Conference, Fordham L. News (Nov. 27, 2017), at https:/news.law.fordham.edu/blog/2017/11/27/hon-charles-n-browerdelivers-keynote-address-international-arbitration-conference. 
to Working Group III and make the process government-led, Brower and his clerk Jawad Ahmad ask: "Are the dice being loaded?" 83

In keeping with the idea of horizontal hostility, Brower and Ahmad proclaim it "baffling" that prominent international arbitrators who have led the field for years would "encourage this "Demolition Derby" and do so "in league with" UNCITRAL. ${ }^{84}$ They single out the CIDS report as the "most directly serious threat" to investor-state arbitration, referring to it as a "research paper" in quotation marks. ${ }^{85}$ Such distrust was heightened by the timing and content of a CIDS Supplemental Report, which was issued a week before the first working group meeting under the title "The Composition of a Multilateral Investment Court and of an Appeal Mechanism for Investment Awards." ${ }^{86}$ This report led certain stakeholders to protest that it made the outcome look predetermined.

As noted, a key critique of some stakeholders that wish to retain investor-state arbitration is that UNCITRAL has been coopted by the European Union to pursue the latter's objective of achieving a multilateral investment court. For instance, Nikos Lavranos claimed that, despite the mandate's open language, it had been "obvious" to everyone in the room when it was adopted that the "only outcome" would be the creation of a multilateral investment court; thus, the European Union had "successfully managed to instrumentalize UNCITRAL." ${ }^{87}$ In response to similar thoughts voiced by Brower in the working group, the chair was quick to respond:

The assignment in this working group is absolutely not the European Commission's proposal. We have our own mandate and the idea that that is what we are here to do is absolutely false.... We are here to work multilaterally together to ... identify concerns and to proceed with our own mandate. ${ }^{88}$

This exchange exposes a central concern for UNCITRAL: it must not be, or be perceived to be, coopted by the European Union or marching toward a predetermined outcome. Part of UNCITRAL's challenge will be forging and maintaining consensus among very differently situated states. Clearly conscious of this dilemma, the chair declared:

Many states in this room ... have had the opportunity to consider many of these issues in detail for a long period of time. And they are ready to move much more quickly in this work and are willing to have these discussions and are having them in good faith but need to see forward momentum in this project.

At the same time, there are many states in this room who have only begun their consideration of this work and would like to have time to adequately discuss and consider and

${ }^{83}$ Charles N. Brower \& Jawad Ahmad, Why The "Demolition Derby" That Seeks To Destroy Investor-State Arbitration?, 91 S. CAL. L. Rev. (forthcoming 2018).

${ }^{84} \mathrm{Id}$.

${ }^{85} \mathrm{Id}$.

${ }^{86}$ Gabrielle Kaufmann-Kohler \& Michele Potestà, The Composition of a Multilateral Investment Court and of an Appeal Mechanism for Investment Awards: CIDS Supplemental Report (2017), available at http://www.uncitral.org/ pdf/english/workinggroups/wg_3/CIDS_Supplemental_Report.pdf.

${ }^{87}$ Nikos Lavranos, The First Steps Towards a Multilateral Investment Court (MIC), EFILA BLOG (July 19, 2017), at https://efilablog.org/2017/07/19/the-first-steps-towards-a-multilateral-investment-court-mic.

${ }^{88}$ Recording: UNCITRAL, Working Group III (Investor-State Dispute Settlement Reform), 35th Sess. (Apr. 24, 2018), available at https://icms.unov.org/CarbonWeb/public/uncitral/speakerslog/453b3b29-9c1f-4537b99e-3c1930558cc7. 
not be rushed into making decisions or into a project that they are not ready to make. As a working group, . . . we have to be respectful of both and try to find a way of achieving balance where we have forward momentum and yet at the same time we have given and continue to give states the opportunity to deliberate and consider without undue delay. ${ }^{89}$

\section{Co-constitutive Relationship Between Forum and Process}

In their study of UNCITRAL as an international lawmaker, Susan Block-Lieb and Terence Halliday theorize that "how law is made affects what law is made." 90 I contend that this relationship is co-constitutive: UNCITRAL as a forum will shape the reform process just as the reform process is likely to shape UNCITRAL as a forum.

It is already clear that UNCITRAL as a forum is shaping the reform process. UNCITRAL's convening power has been demonstrated: around one hundred states and observer entities have been involved in working group meetings so far, along with ten international governmental organizations and several dozen nongovernmental ones. ${ }^{91}$ The sequenced mandate reflects UNCITRAL's consensus-driven process, working to keep on board states that favored a multilateral investment court, as well as those that were opposed or wanted more time to consider their options. It also exemplifies UNCITRAL's preference for incrementalism by allowing states to express their concerns about the existing system and frame the problem before considering potential solutions.

Consensus-based processes often push toward middle ground outcomes, such as retaining investor-state arbitration but adding an appellate body. Given this, the arbitration/court dichotomy is likely to soften over time. We should expect intermediate proposals to be developed that make arbitration look less arbitration-like, such as having the treaty parties select a roster of arbitrators and having either the disputing parties or appointing institutions select the arbitrators for a particular case from that list. We should also predict that court-based proposals will come to look less court-like by, for instance, having a flexible structure that enables the court to convene in different places around the world as required or having the court paid for by a combination of treaty party contributions and user fees.

What might be less clear to date is how this reform process may ultimately shape UNCITRAL. Two examples illustrate the point. First, UNCITRAL has become bolder over time in terms of the difficulty of the topics it has taken on, ${ }^{92}$ but investor-state dispute settlement is probably its most controversial topic to date. The highly political nature of these reform debates has the potential to affect UNCITRAL's working methods.

\footnotetext{
${ }^{89}$ Recording: UNCITRAL, Working Group III (Investor-State Dispute Settlement Reform), 35th Sess. (Apr. 23, 2018), available at https://icms.unov.org/CarbonWeb/public/uncitral/speakerslog/f582d7c7-34ea-439dbe63-46230cbe8675.

${ }^{90}$ Block-Lieb \& Halliday, supra note 63, at 19; see also id. 317-18.

${ }^{91}$ My own coding based on the participants list for the 2017 and 2018 Working Group III meetings.

92 Block-Lieb \& Halliday, supra note 63, at 85.
} 
The longstanding practice in the Commission is to reach decisions by consensus, ${ }^{93}$ which has no precise definition. ${ }^{94}$ In UNCITRAL's practice, "consensus [does] not require unanimity, but [is] instead based on a widely prevailing majority and the absence of a formal objection that would trigger a request for a vote." 95 The chair seeks to reach decisions by consensus. Dissenting states can block consensus and force the issue to the vote, but this is exceptional. In UNCITRAL's history, it happened only once-when a decision was taken on moving its headquarters from New York to Vienna. Yet in the very first issue to be addressed by the current Working Group III-selecting the chair-consensus was not achieved after two days of wrangling, and a vote was called.

The fact that such a standard procedural issue was voted upon reflects the highly charged nature of this process. Some states supported the candidate from Canada, but others opposed him on the basis that Canada had already committed itself to the proposal for a multilateral court. Such voting may be an isolated incident; it may have occurred on an issue of procedure yet would not be replicated on an issue of substance. Still, if voting is resorted to again, which may happen given the contentiousness of these debates, this development would significantly shift UNCITRAL's standard modus operandi.

Second, despite UNCITRAL's claim to inclusiveness, a recent study of its lawmaking across three areas concluded that the United States was the predominant actor, both as a state and through key industry groups controlled by U.S. nationals, and that UNCITRAL had always yielded to major U.S. demands, even if the United States did not get everything it wanted. ${ }^{96}$ The Global North dominated in the forum, whereas the Global South rarely offered a substantive contribution, and Brazil, Russia, India, China, and South Africa (BRICS), as a new complex of emerging economic powers, barely influenced the lawmaking processes. ${ }^{97}$

The working group meetings so far have been a studied contrast to this depiction. UNCITRAL was granted this mandate despite the opposition of the United States, although with the support of another major power from the Global North (the European Union). Russia has been one of the most vocal participants in the debates, while China has played an increasingly significant role. ${ }^{98}$ Brazil and South Africa have been actively engaged and, along with China, have been represented by high-level officials from their respective capitals rather than generalists from their local embassies. India has been less engaged so far. Even so, the five BRICS have taken up about 70 percent as much speaking time as the European Union and all of its member states put together. ${ }^{99}$

The topic is crucial for the Global South and, particularly in the second meeting, a wide range of developing states voiced concerns. Although speaking times are not a proxy for real power, it is noteworthy that, in terms of engagement, the Global South held the floor for

${ }^{93}$ UN Comm'n on Int'l Trade Law, Rep. of Its Forty-Third Session, at 101, UN Doc. A/65/17 (2010), available at https://documents-dds-ny.un.org/doc/UNDOC/GEN/V10/556/48/PDF/V1055648.pdf?OpenElement; UN Comm'n on Int'l Trade Law, Rep. of Its First Session, at 73, UN Doc. A/7216 (Feb. 26, 1968).

${ }^{94}$ For an explanation, see UN Comm'n on Int'l Trade Law, UNCITRAL Rules of Procedure and Methods of Work, UN Doc. A/CN.9/638/Add.4 (Oct. 18, 2007), available at https://documents-dds-ny.un.org/doc/ UNDOC/GEN/V07/875/89/PDF/V0787589.pdf?OpenElement.

${ }^{95}$ July 21 UNCITRAL Report, supra note 3, para. 259.

96 Block-Lieb \& Halliday, supra note 63, at 317-18.

${ }^{97}$ Id. at $163,187,318$.

98 My own coding based on the speakers' log for the 2017 and 2018 Working Group III meetings.

${ }^{99}$ Id. 
longer than the Global North and all of the regional groups have been well represented. ${ }^{100}$ States from the Global South have raised numerous problems with the system, including strongly criticizing the lack of diversity among arbitrators, particularly that arbitrators predominantly come from the Global North yet most frequently sit in cases against states from the Global South. ${ }^{101}$

It remains to be seen whether these states remain as actively involved when the discussion moves from concerns to crafting potential reforms. But developing states have felt the brunt of this system to date and many are clamoring for significant change.

\section{Conclusion: The Path to Pluralism}

We live in an age when Western power in general is weakening and the two major Western powers (the United States and the European Union) are often at odds. Investor-state arbitration reform is a case in point. The West is divided. Non-Western powers, including the BRICS, are becoming more vocal. But they, too, are split.

Puig and Shaffer ultimately argue that "[c]ontexts differ across States, and choices should depend on those contexts" 102 and, thus, that flexibility is likely to be the trend. I agree. As different major states are championing different reform options, it seems probable that current reform efforts will result in a pluralist outcome where multiple approaches coexist. ${ }^{103}$ Instead of lamenting the field's fragmentation, perhaps it is worth celebrating this period of increased freedom, experimentation, and tailoring.

Given the diversity of views and the likelihood of pluralism, it makes sense for states and international institutions to develop a suite of reform options. Some reforms might best be pursued bilaterally and others multilaterally. Some might be more suited to the UNCITRAL process while others are less so. States are yet to make those decisions but framing the options through the lens of pluralism is helpful in identifying the spectrum of reform options and the range of forums that might be involved.

Developing a range of reform options would embody Puig and Shaffer's call for flexibility, as would embracing a variety of legal instruments, some soft and some hard. Flexibility can also be built into specific reform proposals by, for instance, adopting open architectural approaches that permit differently situated states to sign up for new multilateral approaches or institutional mechanisms. In practical terms, pursuing reform may lead states to consider some of the following options:

1. Embracing incremental reforms by, for instance, jointly interpreting treaty provisions, terminating old treaties, and amending or replacing outdated treaties. These steps are currently being examined not only bilaterally, but also in international fora such as UNCTAD and the OECD.

2. Focusing on the ICSID rules amendment process as a key site for incremental reform. Reform of the ICSID rules constitutes an efficient way of ensuring change for a large percentage of future investor-state arbitrations. Using pyramidal incrementalism, some

${ }^{100} \mathrm{Id}$.

${ }^{101}$ Roberts \& Bouraoui, Concerns About Arbitrators, supra note 12 (e.g., Indonesia and Colombia).

102 Puig \& Shaffer, supra note 1 , at 408.

${ }^{103}$ Roberts, UNCITRAL and ISDS Reform, supra note 48. 
reform options developed by ICSID could then be brought to UNCITRAL for debate, modification, and adoption. An arbitrators' code of ethics might be one such example.

3. Developing flexible legal instruments for systematic reform. The Mauritius Convention permits states to decide individually whether to apply a multilateral reform option to their new or existing treaties. This flexible precedent could be used to develop a model for a court or appellate body. Such a treaty could be made even more flexible by permitting states to decide individually whether to opt in to a court and/or an appellate body, or neither.

4. Allowing states to develop diverse preferences in their underlying investment treaties or domestic legislation with respect to certain issues, like the availability of, or requirement to use, domestic courts, mediation, and ombudsmen. Multilateral reform options could permit flexibility and experimentation in this regard at the bilateral level, which some states could use to respond to Puig and Shaffer's call to make international mechanisms complement domestic institutions.

5. Developing any new mechanisms with open architecture. States differ on whether they wish to develop international mechanisms to permit investor-state claims, state-to-state claims, and/or state-investor claims or counterclaims. Multilateral institutional options could thus be developed that would allow states to opt in or out according to their preferences. For instance, states like Brazil and South Africa could potentially opt in for an investment court or appellate body with respect to state-to-state, but not investor-state, arbitration.

More broadly, these reform debates exemplify two significant trends in the current international regime: a desire to recalibrate the importance of economic goals, as many states seek to curb some of the advantages and roles previously accorded to private actors; and shifts in geopolitical power, which are requiring states and international organizations to forge new, more unusual alliances to carry out their agendas. In short, international lawmaking continues, but its content and protagonists are changing. 